\section{Map of Selenium Content in Soil in Japan}

\author{
Takaharu Mizutani,* Kazuo Kanaya, \\ and Takashi Osaka
}

Faculty of Pharmaceutical Sciences, Nagoya City University, 3-1 Tanabe-dori, Mizuho-ku, Nagoya 467-8603, Japan

(Received February 8, 2001; Accepted May 2, 2001)

We present a new selenium (Se) map of Japan in more detail than in our previous report (J. Health Sci., 42, 360-366). It contains 150 measured points, especially in the northeast of Japan. In the new sampling points, we did not find high Se levels and most of the measurements were generally at values below $1 \mathrm{mg} /$ $\mathrm{kg}$. In the Se map of Japan, there are two particularly high measurements, at Mt. Zao $(10 \mathrm{mg} / \mathrm{kg})$ and Tateyama Murodo Jigokudani ( $148 \mathrm{mg} / \mathrm{kg}$ ). These two areas are the origin of a minor branch of the Abukuma River and the Jouganji River, respectively. We also analyzed the Se levels near two major copper mines, Asio and Besshi. We detected high Se content in rocks at both copper mines and an average Se level in soil from the area near the Asio copper mine. The Se level in soil at Besshi was slightly higher than that at the area near the Asio copper mine. We also measured the Se levels of some pyrites in Japan. The Se levels of most pyrites were some ten $\mathrm{mg} / \mathrm{kg}$ higher than the general Se level in soil. This study provides information about the fundamental background values of Se levels in soil and rocks to correlate with Se pollution if it occurs in the future.

Key words — Selenium, Se, soil, pyrite, Soil map, Japan

\section{INTRODUCTION}

Selenium (Se) is an element with two main characteristics: it is both toxic and is an essential part of nutrition. It was first found to be toxic in the early 20th century. It has been well documented that livestock in some regions of the U.S.A. have excess levels of Se, which causes their hooves to drop off, as reviewed by Trelease. ${ }^{1)}$ These livestock ate Se-ac-

\footnotetext{
*To whom correspondence should be addressed: Faculty of Pharmaceutical Sciences, Nagoya City University, 3-1 Tanabe-dori, Mizuho-ku, Nagoya 467-8603, Japan. Tel. \& Fax: +81-52-8363490; E-mail: mizutani@phar. nagoya-cu.ac.jp
}

cumulating plants, such as Astragalus, a kind of vetch. The Se content in these plants can be as high as $2000-5000 \mathrm{mg} / \mathrm{kg}^{2}{ }^{2}$ This accumulation is partially dependent upon the Se content in the soil. ${ }^{3)}$ The toxicity of Se can be a problem for humans. To avoid either Se deficiency or excess in humans, the optimum intake is $50-200 \mu \mathrm{g} / \mathrm{day}^{4}{ }^{4)}$ Humans receive this amount from food as organic and inorganic Se (organic Se is preferable).

$\mathrm{Se}$, as an essential part of nutrition was first reported in 1957 by Schwarz and Foltz, who called it factor $3{ }^{5)}$ Later Se was found to occur in the form selenocysteine ( $\mathrm{Sec}$ ), and glutathione peroxidase (GPx) also contains Sec at the active site. There are many Se-proteins, such as $5^{\prime}$ iodothyronine deiodinase, thioredoxin reductase, selenoprotein-P, and the GPx family. ${ }^{6}$ The Sec codon is UGA which it shares with the major stop codon UGA. Sec has its tRNA and codon and is called as the 21 st amino acid. We previously clarified the recognition sites on the tRNA ${ }^{\text {Sec }}$ for Sec synthase. ${ }^{7)}$ The first step in the discrimination mechanism between the stop and Sec UGA codons was clarified ${ }^{8}{ }^{8}$ However, most of the mechanism remains to be resolved.

In the preparation of a Se map of Japan, we initially reported a basic version. ${ }^{9)}$ In the previous map, the highest Se level measured was at Tateyama Murodo Jigokudani at a concentration of $148 \mathrm{mg} / \mathrm{kg}$. The broad area of Murodo showed high Se levels. Another high Se level of $10 \mathrm{mg} / \mathrm{kg}$ was at Mt. Zao. It was suggested that the reason for the high Se level in these two areas was because they are volcanoes and therefore generate sulfur compounds. However, soils from many other volcanoes, such as Mt. Unzen and Mt. Tokachidake and ash from Mt. Pinatubo in Philippines, have low Se levels.9 ${ }^{9}$ This was also confirmed by the finding of Se deficiency at volcanoes in New Zealand. ${ }^{10)}$ In addition to soil analyses, we measured the Se level in some Astragalus plants in Japan, ${ }^{9)}$ and did not find high Se levels in vetches, which are well known to be Se accumulators in North America. ${ }^{1)}$ We also measured the Se level in some grasses growing in high Se level areas of Murodo or Mt. Zao, and did not find any Se accumulator plants. ${ }^{9)}$ We found high Se levels near the Besshi copper mine and therefore report the Se levels in soils and rocks from the areas around the two major copper mines in Japan, Asio and Besshi. We measured the Se content in some pyrites produced in Japan, because Berzelius found Se in pyrite from his mine. 
$0.0 .2 \mathrm{mg} / \mathrm{kg}$

- $0.2-1 \mathrm{mg} / \mathrm{kg}$

- $1-3 \mathrm{mg} / \mathrm{kg}$

- $>3 \mathrm{mg} / \mathrm{kg}$

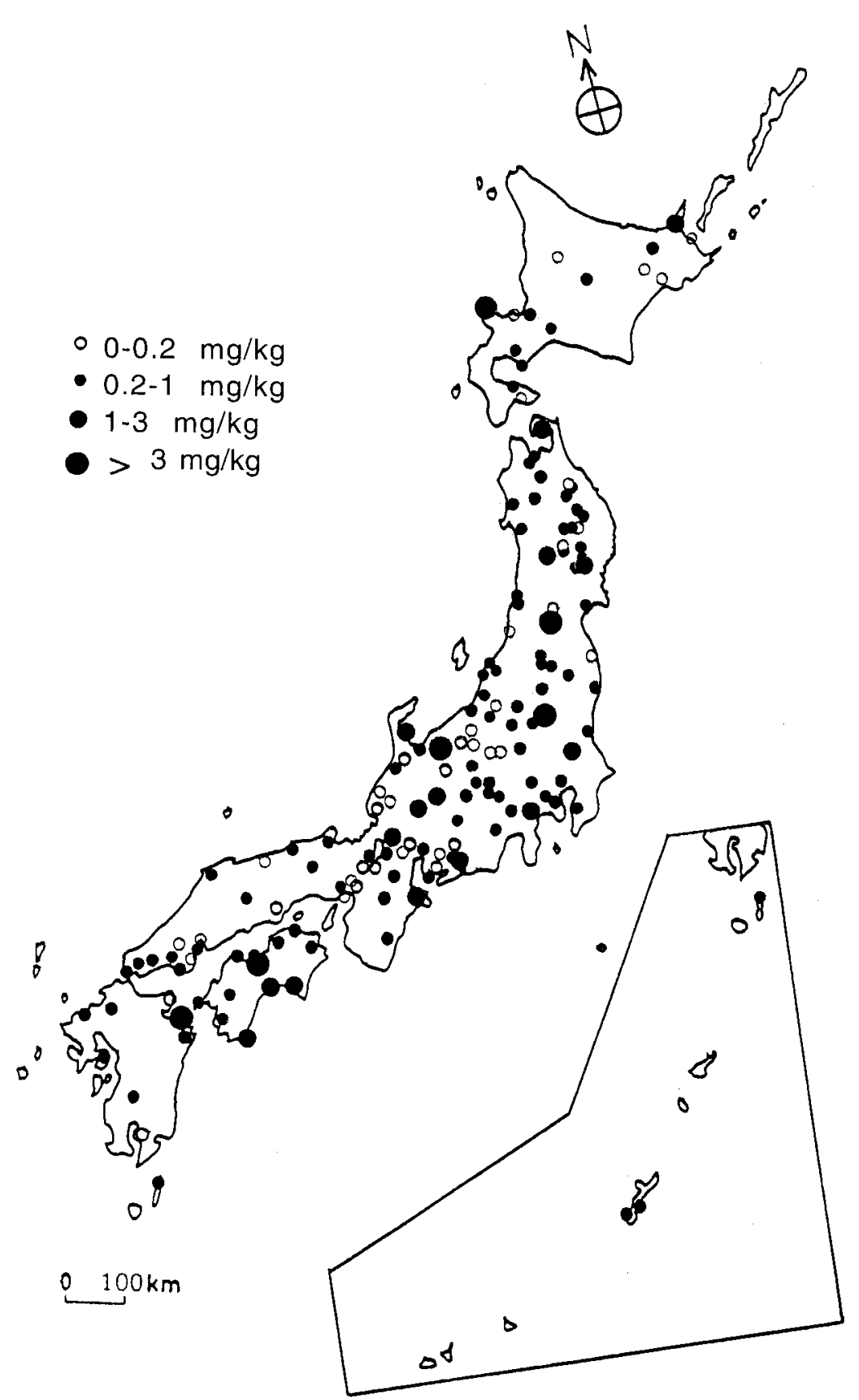

Fig. 1. Japanese Selenium Map of Surface Soil

The inset shows the southern Ryukyu Islands of Japan. Se levels are indicated in the figure by circles.

\section{MATERIALS AND METHODS}

Analyses of Se were carried out according to the previous methods, ${ }^{9)}$ as follows. Samples of the surface soil (at a depth of $0-20 \mathrm{~cm}$ ) were collected at the points indicated in Fig. 1. We used original soil, not cultivated soil. Visible organic materials were removed from the samples and fine grains less than $0.1 \mathrm{~mm}^{3}$ (rock samples were grained and used) were used for the measurements. The soil was dried for
2 days at $50^{\circ} \mathrm{C}$. The amount of Se in each 5 -mg dried sample was measured in triplicate by fluorometry with diaminonaphthalene (DAN, a product of Aldrich). ${ }^{11)}$ Mixed acids composed of concentrated sulfuric acid $30 \mu \mathrm{l}$ and $60 \%$ perchloric acid $20 \mu \mathrm{l}$ were added to each sample, which was then heated at $200^{\circ} \mathrm{C}$ for $30 \mathrm{~min}$. Then, $6 \mathrm{M} \mathrm{HCl} 0.25 \mathrm{ml}$ was added, and the solution was allowed to stand for $30 \mathrm{~min}$ at $100^{\circ} \mathrm{C}$ to reduce $\mathrm{Se}$ (VI) to Se (IV). Fifty percent formic acid $(0.25 \mathrm{ml})$ and stabilizing solu- 
tion $(0.5 \mathrm{ml})$ containing EDTA $4.7 \mathrm{mg}$ and hydroxylamine- $\mathrm{HCl} 12.5 \mathrm{mg}$ were added, and the mixture was adjusted to about $\mathrm{pH} 2$ with $7 \mathrm{M}$ ammonia $0.5 \mathrm{ml}$. DAN solution $0.25 \mathrm{ml}(0.5 \mathrm{~g} / \mathrm{l}$ of $0.1 \mathrm{M} \mathrm{HCl})$ was washed twice with cyclohexane and then added to the mixture and heated at $50^{\circ} \mathrm{C}$ for $20 \mathrm{~min}$. After heating, cyclohexane $1 \mathrm{ml}$ was added and mixed. The cyclohexane layer was measured at $360 \mathrm{~nm}$ (excitation wavelength) and at $520 \mathrm{~nm}$ (emission wavelength). The amount of Se was calculated from the mean value of three determinations using a standard curve based on authentic Se. The standard inorganic Se used was a product of Merck for atomic absorption spectroscopy. To normalize the Se levels in soil samples, we also measured the Se level in a standard soil sample (JLK-1 Lake sediment, supplied by the Geological Survey of Japan). Some pyrite samples were generous gifts from Dr. Haruyuki Yutaka of the Geological Survey of Japan, Yatabe, Ibaragi, Japan.

\section{RESULTS AND DISCUSSION}

After the previous study, ${ }^{9}$ in which we reported 70 sampling points in constructing a Se map of Japan, we accumulated an additional localities 80 (all 150 sampling points and Se levels at each point are shown in Table 1) and those findings are plotted in Fig. 1. The present map contains some sampling points in the Tohoku (northeast) region of Japan and the San-In area. In the previous map, we showed that the highest Se levels were at Murodo Jigokudani of Mt. Tateyama, Mt. Zao, and the area near the Besshi copper mine (the level of Murodo Jigokudani was $148 \mathrm{mg} / \mathrm{kg}$ ). We did not find plants containing high Se levels in the Murodo Jigokudani area. ${ }^{9}$ In the present study, we did not find high levels of Se but only normal levels between 0 to $1 \mathrm{mg} / \mathrm{kg}$. Many localities in the northeast region except for Mt. Zao had normal Se levels, as shown in Fig. 1. Areas with slightly elevated Se content were from Mt. Tateyama to the Mino district of Gifu prefecture, and the south area of Shikoku island. This Se map of Japan may play a role in providing background values if $\mathrm{Se}$ pollution occurs.

In the previous study, we found high Se content in soil obtained near the region of the Besshi copper mine. Therefore we measured the Se levels in areas near two major old copper mines, Asio and Besshi, as shown in Tables 2 and 3, respectively. These two areas were famous for sulfur pollution when actively producing copper. Table 2 shows the Se levels in soil and rocks obtained from the Asio copper mine, such as copper stones and soil in caves. Rocks from the copper mine had high Se levels of $4.5 \mathrm{mg} / \mathrm{kg}$ and one copper ore sample contained $2.2 \mathrm{mg} / \mathrm{kg}$. However, soil samples contained average Se levels. Previously, this area was polluted by sulfur compounds when copper was produced, but rocks that produced copper did not contain high Se levels, as selenite and/or elemental Se. Analyses of the Se level of Asio showed higher Se content in the samples obtained from the Nikko area, suggesting that this was due to the proximity of Asio copper mine. However, the Se levels at the Asio copper mine were low. These findings clarified that there is no Se pollution in the Asio area.

Table 3 shows Se levels in samples obtained from the area of the Besshi copper mine, which is no longer in production and has been converted into the Besshi Minetopea Museum. We obtained some samples from Minetopia and measured the Se levels. In contrast to the findings in shown Table 2 from the Asio copper mine, some soil obtained from the area of the Besshi mine contained high levels of Se from $1.0-4.5 \mathrm{mg} / \mathrm{kg}$, as well as high levels in copper rocks $(8.7 \mathrm{mg} / \mathrm{kg})$. This suggested that the area near the Besshi copper mine may be slightly polluted by Se as well as sulfur compounds.

In 1817, Berzelius found Se as red precipitates at the bottom of a lead chamber used in the process to produce sulfuric acid from sulfite gas by burning pyrite from his mine. Pure pyrite is $\mathrm{FeS}_{2}$, but it is possible that impure pyrite contains some Se. Therefore we measured the Se content in pyrite from Japan, generously supplied by the Geological Survey of Japan, as shown in Table 4. The maximum Se level in Table 4 is $330 \mathrm{mg} / \mathrm{kg}$ in pyrite obtained from Goto Island, Nagasaki prefecture. With the exception of pyrite samples from Hitachi and Chichibu, the Se levels in other pyrite samples were some ten $\mathrm{mg} / \mathrm{kg}$. Table 4 also shows the findings copper rock from Ikuno in Hyogo prefecture and Kiwa-cho in Mie prefecture, Japan.

Keshan, from which the name of the Se deficiency syndrome Keshan disease came, is located in the northeast area of China (the eastern terminal of the Eurasian continent). ${ }^{12)}$ This disease occurs due to the low Se levels in the soil and crops. The Japanese islands separated from the Eurasian continent in the ancient past. Therefore it is possible that soil from Japan has low Se levels. However, as shown in this study, Se levels in Japan are generally nor- 
Table 1. Sampling Points in Figure 1 and Se Levels

\begin{tabular}{|c|c|c|c|}
\hline \multirow{2}{*}{$\begin{array}{l}\text { Point } \mathrm{Se}(\mathrm{mg} / \mathrm{kg} \mathrm{d} \\
\text { Sharigun Kiyosatocho, Hokkaido pref. }\end{array}$} & Se (mg/kg dry weight) & \multirow{2}{*}{$\begin{array}{l}\text { Point } \\
\text { Inawasiroko, Fukushima pref. }\end{array}$} & Se (mg/kg dry weight) \\
\hline & 0.33 & & 0.59 \\
\hline Siretoko-toge, Hokkaido pref. & 1.24 & Tsukuba City Hachimandai, Ibaragi pref. & 1.13 \\
\hline Shari-jinja, Hokkaido pref. & 0.25 & Katsuta Station, Ibaragi pref. & 0.42 \\
\hline Nemuro Notsukemisaki, Hokkaido pref. & 0.16 & Nikko Nishisando, Tochigi pref. & 1.52 \\
\hline Akanko, Hokkaido pref. & 0.17 & Nikko Honden, Tochigi pref. & 0.81 \\
\hline Kushiro-sitsugen, Hokkaido pref. & 0.17 & Nikko Okusha, Tochigi pref. & 4.90 \\
\hline Tokachidake, Hokkaido pref. & 0.36 & Chuzenjiko Hutarasan-Chuguji, Tochigi pref. & 0.82 \\
\hline Asahikawa City, Hokkaido pref. & 0.15 & Kegonnotaki, Tochigi pref. & 0.52 \\
\hline Otaru City, Hokkaido pref. & 0.05 & Tsudo Station, Tochigi pref. & 0.66 \\
\hline Sapporo City Hokudai, Hokkaido pref. & 0.87 & Osegahara-Yamanohana, Gunma pref. & 0.29 \\
\hline Sapporo Hitsujigaoka, Hokkaido pref. & 0.27 & Takasaki Castle, Gunma pref. & 0.22 \\
\hline Chitose Air Port, Hokkaido pref. & 0.31 & Mizugami City Tone River, Gunma pref. & 0.19 \\
\hline Muroran City Hachimangu, Hokkaido pref. & 0.30 & Kisarazu City Academia Park, Chiba pref. & 0.25 \\
\hline Touyako Nakajima, Hokkaido pref. & 0.39 & Urawa City Otakubo, Saitama pref. & 0.93 \\
\hline Hakodate Goryoukaku Hokkaido pref. & 0.34 & Bunkyoku Hongo Sanshiroike, Tokyo pref. & 0.74 \\
\hline Shakotan-misaki Hokkaido pref. & 5.29 & Akasaka Hie-jinja, Tokyo pref. & 0.61 \\
\hline Oirase, Aomori pref. & 0.75 & Yushima Seido, Tokyo pref. & 0.69 \\
\hline Aomori City Uto-jinja, Aomori pref. & 0.56 & Machida City, Tokyo pref. & 0.43 \\
\hline Towadako Towada-jinja, Aomori pref. & 0.84 & Kiyose City, Tokyo pref. & 0.69 \\
\hline Sannaimaruyama, Aomori pref. & 0.26 & Tokyo University Komaba Campus, Tokyo pref. & 1.06 \\
\hline Chusonji Konjikido, Iwate pref. & 1.25 & Shibuy-ku Saruraku-iseki, Tokyo pref. & 1.93 \\
\hline Morioka Castle, Iwate pref. & 0.09 & Yokohama Aoba Park, Kanagawa pref. & 0.53 \\
\hline Yudamachi Kinshuko, Iwate pref. & 0.37 & Kamakura Kenchoji, Kanagawa pref. & 0.74 \\
\hline Sangi-jinja, Iwate pref. & 0.84 & Hakonemachi Owakudani Red Soil, Kanagawa pref. & 1.62 \\
\hline Sawauchimura Gingakougen, Iwate pref. & 0.14 & Odawara Castle, Kanagawa pref. & 0.36 \\
\hline Mizusawa Kumano-jinja, Iwate pref. & 0.45 & Nakakomagun Showamachi, Yamanashi pref. & 0.50 \\
\hline Iwatemachi Numamiya-jinja, Iwate pref. & 0.68 & Obuchizawa Station, Yamanashi Pref. & 0.61 \\
\hline Ichinoseki Genbikei, Iwate pref. & 0.25 & Minamikomagun Shimobe-onsen, Yamanashi pref. & 0.46 \\
\hline Kitakami Yasuragi, Iwate pref. & 0.94 & Nagano City Zenkoji Park, Nagano pref. & 0.14 \\
\hline Ninohe Kindaichi-onsen, Iwate pref. & 0.16 & Iiyama Station, Nagano pref. & 0 \\
\hline Ninohe Yakushido, Iwate pref. & 0.29 & Karuizawa Station, Nagano pref. & 0 \\
\hline Kitakamidanso, Iwate pref. & 0.04 & Komoro City Kaikoen, Nagano pref. & 0.14 \\
\hline Jouhojimachi, Iwate pref. & 0.31 & Hakuba Happo, Nagano pref. & 0.14 \\
\hline Tamayamamura Himegamiyama, Iwate pref. & 0.60 & Shinano Omachi, Nagano pref. & 0.15 \\
\hline Tazawako Sengantoge, Iwate pref. & 0.49 & Yatsugatake Tsuboniwa, Nagano pref. & 0.08 \\
\hline Zaou Okama, Miyagi pref. & 10.0 & Yatsugatake Amigasadake, Nagano pref. & 2.42 \\
\hline Zaou Kattadake, Miyagi pref. & 22.3 & Kurumayama Kogen, Nagano pref. & 0.26 \\
\hline Matsushima, Miyagi pref. & 1.76 & Shirakabako, Nagano pref. & 0.33 \\
\hline Shiogama City Susonodacho, Miyagi pref. & 0.42 & Kisohukushima Station, Nagano pref. & 0.27 \\
\hline Higashinosiro City, Akita pref. & 0.72 & Kisokomagatake Senjojiki, Nagano pref. & 0.27 \\
\hline Akita City Senshu Park, Akita pref. & 0.34 & Kiso-Ontake, Nagano pref. & 0.81 \\
\hline Odate Station, Akita pref. & 0.29 & Niigata City, Niigata pref. & 0.59 \\
\hline Yokote City Yokotekoen, Akita pref. & 1.51 & Murakami Station, Niigata pref. & 0.19 \\
\hline Kawanishicho, Yamagata pref. & 0.59 & Kitakanbaragun Yasudamachi, Niigata pref. & 0.87 \\
\hline Yamadera, Yamagata pref. & 0.20 & Santogun Koshijimachi, Niigata pref. & 0.24 \\
\hline Sakata City Yagumo-jinja, Yamagata pref. & 0.26 & Teradomari, Niigata pref. & 0.24 \\
\hline Tsuruoka City, Yamagata pref. & 0.51 & Yuzawa Naeba, Niigata pref. & 0.48 \\
\hline Aizukogen, Fukushima pref. & 0.27 & Tsunan, Niigata pref. & 0.14 \\
\hline Iwaki City Taira Castle, Fukushima pref. & 0.41 & Nakakubikigun Ogatacho, Niigata pref. & 0.31 \\
\hline Haranomachi City, Fukushima pref. & 0.19 & Toyama Station, Toyama pref. & 0.33 \\
\hline Aizuwakamatsu Tsurugajo, Fukushima pref. & 0.31 & Oyabe City, Toyama pref. & 0.08 \\
\hline Koriyama City Atago-jinja, Fukushima pref. & 0.40 & Tateyama Station, Toyama pref. & 0.93 \\
\hline Kitagata Station, Fukushima pref. & 0.27 & Kanazawa Station, Ishikawa pref. & 0.22 \\
\hline
\end{tabular}


Table 1. Continued

\begin{tabular}{|c|c|c|c|}
\hline \multicolumn{2}{|c|}{$\begin{array}{ll}\text { Point } & \mathrm{Se}(\mathrm{mg} / \mathrm{kg} \text { dry weight }) \\
\end{array}$} & \multirow{2}{*}{$\begin{array}{l}\text { Point } \\
\text { Ikuno Pyrite, Hyogo pref. }\end{array}$} & Se (mg/kg dry weight \\
\hline Wajima City Sosogi Kaigan, Ishikawa pref. & 0.08 & & 0.31 \\
\hline Hakui City Kitataisha, Ishikawa pref. & 1.01 & Sonikogen, Nara pref. & 0.27 \\
\hline Wakura-onsen, Ishikawa pref. & 1.78 & Todaiji, Nara pref. & 0.37 \\
\hline Oyama-jinja, Ishikawa pref. & 1.00 & Horyuji, Nara pref. & 0.30 \\
\hline Sakaicho, Fukui pref. & 0.18 & Asukamura Ishibutai, Nara pref. & 0.22 \\
\hline Maruoka Castle, Fukui pref. & 0.23 & Nachitaisha, Wakayama pref. & 0.22 \\
\hline Eiheiji, Fukui pref. & 0.04 & Sihgu City Kumano-Hayatama-jinja, Wakayama pref. & 0.49 \\
\hline Awara-onsen, Fukui pref. & 0.24 & Kurayoshi Imazaike, Tottori pref. & 0.15 \\
\hline Fukui City Chuo Park, Fukui pref. & 0.07 & Tottori City, Tottori pref. & 0.38 \\
\hline Nenohara-kougen, Gifu pref. & 0.79 & Izumotaisha, Shimane pref. & 0.58 \\
\hline Gujohachiman Atago-jinja, Gifu pref. & 1.75 & Muikamachi Churengawa, Shimane pref. & 0.10 \\
\hline Neodani, Gifu pref. & 2.11 & Okayama City Ohkubo, Okayama pref. & 0.06 \\
\hline Nakatsugawa Kamienasan-jinja, Gifu pref. & 0.46 & Niimi City Senya, Okayama pref. & 0.23 \\
\hline Ena City, Gifu pref. & 0.08 & Otake City Kamei Castle, Hiroshima pref. & 0.34 \\
\hline Ibukiyama, Gifu pref. & 1.15 & Hiroshima City Hijiyama, Hiroshima pref. & 0.10 \\
\hline Kamitakaramura Shinhotaka, Gifu pref. & 0.18 & Itsukushima-jinja, Hiroshima pref. & 0.43 \\
\hline Gifu City Mitahora, Gifu pref. & 0.45 & Hikari City Kanbaien, Yamaguchi pref. & 0.57 \\
\hline Kosakacho Nigorigo-onsen, Gifu pref. & 1.78 & Shimonoseki City Daigakucho, Yamaguchi pref. & 0.40 \\
\hline Fujisan, Shizuoka pref. & 0.26 & Yamaguchi City Yoshida, Yamaguchi pref. & 0.74 \\
\hline Hamanako Tsuzuki-jinja, Shizuoka pref. & 1.11 & Mine City Atsuho, Yamaguchi pref. & 0.97 \\
\hline Hamanako Kosaicho, Shizuoka pref. & 1.22 & Tonogun Kanocho, Yamaguchi pref. & 0.24 \\
\hline Nagoya City University, Aichi pref. & 0.31 & Kugagun Wagicho, Yamaguchi pref. & 0.15 \\
\hline Kasugai City, Aichi pref. & 0.11 & Tokushima City Kawauchimachi, Tokushima pref. & 0.31 \\
\hline Amagun Sayacho, Aichi pref. & 0.12 & Takamatsu City Ritsurinkoen, Kagawa pref. & 0.53 \\
\hline Toyota City Takatori-jinja, Aichi pref. & 0.18 & Kotohira-jingu, Kagawa pref. & 0.37 \\
\hline Kitasidaragun Tomiyamamura, Aichi pref. & 0.11 & Yashima, Kagawa pref. & 0.45 \\
\hline Gamagori City, Aichi pref. & 0.19 & Niihama Station, Ehime pref. & 0.89 \\
\hline Sidaragun Horaicho, Aichi pref. & 0.26 & Satamisaki Misaki, Ehime pref. & 0.34 \\
\hline Chitahanto Toyohama, Aichi pref. & 0.80 & Uchiko, Ehime pref. & 0.28 \\
\hline Fujiwaradake, Mie pref. & 0 & Uwajima City, Ehime pref. & 0.25 \\
\hline Suzukasanmyaku Buheitoge, Mie pref. & 0.25 & Kochi City Keraotsu, Kochi pref. & 1.03 \\
\hline Isejingu Gegu, Mie pref. & 1.24 & Tosashimizu City, Kochi pref. & 1.09 \\
\hline Seta River, Shiga pref. & 0.11 & Akigun, Kochi pref. & 1.66 \\
\hline Nishi-otsu, Shiga pref. & 0.35 & Dazaihu Tohuro, Fukuoka pref. & 0.48 \\
\hline Tagacho, Shiga pref. & 0.55 & Higashimatsuuragun Hamatamacho, Saga pref. & 0.66 \\
\hline Eigenji, Shiga pref. & 0.21 & Unzen-onsen, Nagasaki pref. & 0.12 \\
\hline Kiyomidzudera, Kyoto pref. & 0.19 & Saganoseki, Ooita pref. & 4.20 \\
\hline Yosagun Mineyamacho, Kyoto pref. & 0.50 & Toana, Ooita pref. & 0.41 \\
\hline Kyoto Hushimiku Hujinomori-jinja, Kyoto pref. & 0.15 & Kunisakihanto, Ooita pref. & 0.18 \\
\hline Hieizan, Kyoto pref. & 0.46 & Sakurajima, Kagoshima pref. & 0.18 \\
\hline Hirakata City, Osaka pref. & 0.31 & Tanegashima Nishiomote City, Kagoshima pref. & 0.65 \\
\hline Asahi-ku Yodogawa-kasenshiki, Osaka pref. & 0.04 & Hishikari-kozan, Kagoshima pref. & 0.70 \\
\hline Senri, Osaka pref. & 0.16 & Gushikami, Okinawa pref. & 0.21 \\
\hline Rokkosan Arashino-oka, Hyogo pref. & 0.28 & Urazae City, Okinawa pref. & 0.32 \\
\hline Arima-onsen, Hyogo pref. & 0.90 & Ginowan City, Okinawa pref. & 0.52 \\
\hline Kobe Port-island, Hyogo pref. & 0.31 & Yomitan, Okinawa pref. & 0.56 \\
\hline
\end{tabular}

mal except for a few certain areas, such as Murodo Jigokudani of Mt. Tateyama and some pyrite rocks. One study reported acute Se toxicity after swallowing gun blue, a lubricant solution. ${ }^{13)}$ The symptoms were the sudden onset of profuse, watery diarrhea and vomiting. ${ }^{13)}$ We measured Se levels in soil and rocks by fluorometry using DAN as described in Materials and Methods. The Se compounds in the 
Table 2. Se Content in the Soil and Rocks from the Area near the Asio Copper Mine

\begin{tabular}{lc}
\hline \hline Sampling point & Se $(\mathrm{mg} / \mathrm{kg}$ dry weight $)$ \\
\hline Oziri Beach of Chuzenji Lake, Tochigi pref. & 0.68 \\
Chuguji of Chuzenji Lake, Tochigi pref. & 0.82 \\
Kegon Falls, Tochigi pref. & 0.52 \\
Tudou Station, Tochigi pref. & 0.66 \\
Asio copper rock 1, Tochigi pref. & 0.26 \\
Asio copper rock 2, Tochigi pref. & 4.50 \\
Wall of copper mine, Tochigi pref. & 2.21 \\
Iron rust in copper mine caves, Tochigi pref. & 0.25 \\
Natural CuSO 4 crystals in caves, Tochigi pref. & 0.51 \\
Asio Pottery, Tochigi pref. & 0.79 \\
\hline
\end{tabular}

Table 3. Se Content in the Soil from the Area near the Besshi Copper Mine

\begin{tabular}{lc}
\hline \hline Sampling point & Se $(\mathrm{mg} / \mathrm{kg}$ dry weight $)$ \\
\hline Bus stop at Besshi Minetopia, Ehime pref. & 2.16 \\
Entrance of Besshi Minetopia, Ehime pref. & 4.54 \\
Soil at exit of cave, Besshi Minetopia, Ehime pref. & 1.02 \\
Rock at exit of cave, Besshi Minetopia, Ehime pref. & 0.24 \\
Rock as a souvenir of Besshi Minetopia, Ehime pref. & 8.69 \\
Soil from a gutter, Besshi Minetopia, Ehime pref. & 0.37 \\
Niihama Station, Ehime pref. & 0.89 \\
Mitsuzaki of Sata Cape, Ehime pref. & 0.34 \\
\hline
\end{tabular}

Table 4. Se Content in Pyrite and Copper Rocks from Japan

\begin{tabular}{lc}
\hline \hline Sampling point & Se (mg/kg dry weight) \\
\hline Pyrites & \\
Kamikita mine, Aomori pref. & 22.4 \\
Osarizawa mine, Akita pref. & 31.7 \\
Sayama mine, Akita pref. & 28.5 \\
Awanoyu mine, Yamagata pref. & 74.3 \\
Hitachi mine, Ibaraki pref. & 6.4 \\
Chichibu mine, Saitama pref. & 5.6 \\
Konuki mine, Niigata pref. & 17.7 \\
Harimichi mine, Nara pref. & 24.0 \\
Kanbe mine, Nara pref. & 19.4 \\
Goto mine, Nagasaki pref. & 330 \\
Peru (from the Museum of the University of Wisconsin) & 61.4 \\
Copper rocks & \\
Besshi & 8.69 \\
Asio & 4.50 \\
Ikuno, Hyogo pref. & 0.31 \\
Kiwa-cho, Mie pref. & 47.6 \\
\hline
\end{tabular}

soil and rocks are hydrolyzed in mixed acids. However, insoluble Se compounds in soil have previously been reported. ${ }^{14)}$ Therefore it is possible that insoluble Se in mixed acids was not measured and the levels reported for some areas may be lower than the total Se value.

Acknowledgements We are deeply indebted to Dr. Y. Yutaka of the Geological Survey of Japan for the supply of pyrite samples from Japan. Most soil samples in the Tohoku area were collected by Dr. Hiromichi Hayashi of Nagoya City University. We also appreciate numerous supporters who provided Japanese soil samples.

\section{REFERENCES}

1) Trelease, S. F. (1942) Bad earth. Science Monthly, 54, 12-28.

2) Beath, O. A., Draize, J. H., Effson, H. F., Gilbert, C. S. and McCreary, O. C. (1934) Certain poisonous plants of Wyoming activated by selenium and their associates with respect to soil types. J. Am. Pharm. Assoc., 23, 94-97.

3) Moxon, A. L. and Olson, O. E. (1974) Selenium in agriculture. In Selenium (Zingaro, R. A. and Cooper, W. C., Eds.) Van Nostrand Reinfeld Co., New York, pp. 675-707.

4) Sando, K., Nezu, R., Takagi, Y. and Okada, A. (1990) Platelet glutathione peroxidase activity in long-term total parenteral nutrition with/without selenium supplementation. In Trace Elements in Clinical Medicine (Tomita, H., Ed.), Springer-Verlag, Tokyo, pp. 239-242.

5) Schwarz, K. and Foltz, C. M. (1957) Selenium as an integral part of factor 3 against dietary necrotic liver degeneration. J. Am. Chem. Soc., 79, 32923293.

6) Himeno, S. and Imura, N. (2000) New aspects of physiological and pharmacological roles of selenium. J. Health Sci., 46, 393-398.

7) Mizutani, T., Goto, C. and Totsuka, T. (2000) Mammalian selenocysteine tRNA, its enzymes and selenophosphate. J. Health Sci., 46, 399-404.

8) Atkins, J. F. and Gesteland, R. F. (2000) The twentyfirst amino acid. Nature, 407, 463-464.

9) Mizutani, T., Tanabe, K., Watanabe, K. and Goto, M. (1996) Selenium contents in Astragalus and uncultivated soils in Japan. J. Health Sci., 42, 360366.

10) Oldfield, J. E. (1995) Selenium in Maps, Se-Te Development Association, Inc., Grimbergen, Belgium, pp. 1-7.

11) Parker, C. A. and Harvey, L. G. (1962) Luminescence of some piazselenols. Analyst, 87, 558-565.

12) Keshan Disease Research Group (1979) 
Epidemiologic studies on the etiologic relationship of selenium and Keshan disease. Chin. Med.J., 92, 477-482.

13) Ruta, D. A. and Haider, S. (1989) Attempted murder by selenium poisoning. Br. Med. J., 299, 316-317.
14) Yamada, H., Miyamoto, T., Yasuda, A., Hattori, T. and Yonebayashi, K. (1974) Determination of trimethylselenonium ion and its behavior in soil. Soil Sci. Plant Nutr., 40, 49-56. 